\section{RESTORING THE BALANCE: LEARNING LESSONS FROM CASES REFERRED TO EU PILOT PROJECT THAT PROVIDES VICTIM REQUESTED RESTORATIVE JUSTICE IN THE THAMES VALLEY, UK}

This article describes lessons learned from a pilot project that delivers Restorative Justice (RJ) to victims of crime referred by agencies supporting victims and victim self-referrals. The project involves a partnership of agen-

1 GeoffEmerson, Social worker, e- mail: geoffemersonwork@gmail.com

2 Louise Carrington-Dye, Restorative Justice Facilitator - Thames Valley Probation and Community Rehabilitation Company

${ }^{3}$ Graham Dix, Restorative Justice Facilitator - Thames Valley Probation and Community Rehabilitation Company

${ }^{4}$ Diane Grammer, Restorative Justice Facilitator - Thames Valley Probation and Community Rehabilitation Company

Received: May, 2014

Accepted: September, 2014

UDK 347.918 : 343.988

DOI 10.3935/jsr.v22i1.23

Geoff Emerson ${ }^{1}$

Louise Carrington-

Dye $^{2}$

Graham Dix ${ }^{3}$

Diane Grammer ${ }^{4}$

Thames Valley Partnership

Chilton

United Kingdom

Key words:

Lessons, Restorative Justice (RJ), victims, access. 
cies in the Thames Valley, working as part of a wider European Collaboration, to extend $R J$ services to victims at the post-sentencing level. We provide access to $R J$ for victims, whilst protecting their rights and preventing re-victimisation, in accordance with EU directive 2012/29/EU (European Commission, 2012).

The context and methodology of pilot project are explained. Lessons learned from practice through team case discussion and supervision are then identified and described. The cases are summarised in a table which outlines their key features and acts as a point of reference in relation to the lessons learned.

Cases are ongoing at the time of writing. The lessons may not always be clear cut and finalised. We hope that this approach will demonstrate the process of learning from experience and practice as the project develops. Whilst ours is not a rigorously scientific approach, we hope it offers a chance to understand the dilemmas and issues presented by a model which starts from a victim's request for $R J$. Independent evaluation, involving interviews with victims, referrers and offenders who have participated in the pilot project, follows at a later stage.

\section{INTRODUCTION}

\section{The UK context for restorative justice (RJ)}

RJ has been part of the youth justice process for well over a decade, but the extensive development of $\mathrm{RJ}$ in the adult justice system is a very recent and rapid phenomenon (Emerson, 2011, 2012). Despite provision being made for $\mathrm{RJ}$ in the Criminal Justice Act 2003, few resources were made available to implement those provisions. The UK Coalition Government is now committed to ensuring that $\mathrm{RJ}$ is 'accessible at every stage of the criminal justice process, from initial arrest through to prison, for those victims and offenders who are willing.' (Ministry of Justice, 2012). The Government Action Plan, from which this quotation is taken, describes the barriers to the development of RJ and demonstrates how they will be overcome by taking taken steps to:

- improve access to restorative justice for victims and offenders;

- make the public and criminal justice practitioners aware of RJ as an option;

- make skilled facilitators available nationally (by developing increased capacity through training);

- and by continuing to build the evidence base as to what is best practice.

Since the publication of the Action Plan there has been:

- legislation (Crime and Courts Act 2013) to make RJ available to courts presentence (unlike other countries in Europe, in the UK the majority of RJ to date has taken place post-sentence); 
- a nationwide programme of training and support to enable staff in prisons and probation to undertake the delivery of RJ with offenders (primarily with those convicted of offences of violence and burglary). These developments are described in a management manual prepared by TV Partnership (NOMS, 2013);

- a revision of the Code of Practice for Victims of Crime (Ministry of Justice, 2013) to make RJ available to victims at key points in their journey through the criminal justice process;

- and the allocation of funds to Police and Crime Commissioners (PCCs) to fund the delivery of $\mathrm{RJ}$ as a part of their role to ensure victims can have access to the services they need to recover from the impact of crime (Thames Valley Police and Crime Commissioner, 2014)

These developments point to a very optimistic picture for the development of $R J$ in the UK and a very strong drive towards RJ being delivered with a focus on developing access for victims. For a long time most RJ in the UK had been initiated by approaching victims after the offender had indicated their willingness to take part. Shapland suggests that advocates of RJ will be 'rejoicing' at these developments (Shapland, 2013).

\section{The rationale for our pilot project}

Thames Valley Probation has a long history of collaboration with Victim Support, Thames Valley Partnership, the Police and local prisons in the delivery of RJ. We participated in the ground-breaking research reported on by Professor Shapland (Shapland et al, 2006, 2007, 2011) and have'mainstreamed' RJ, using a conferencing approach with both prison and community sentences. In 2010 we became involved in an EU funded collaboration with European partners to share practice via conferences and study visits. This work is fully described in two publications (Lummer, Hagemann and Tein, 2011; Lummer, Nahrwold and Suess, 2012). A further collaboration was proposed to develop the delivery of $\mathrm{RJ}$ at the post sentence level in accordance with the EU Directive (European Commission, 2012). This directive seeks to promote access to RJ for victims and protect their rights through a safe process which prevents re-victimisation. For us, this presented a golden opportunity to develop our range of RJ services to offer open access to RJ victims through this pilot project. We had been aware for some time that victims in the Thames Valley had found it difficult to access RJ (see Sari's story in Lummer, Nahrwold and Suess, 2012).

We therefore applied for funds, within the current EU funded collaboration (Project description and conference papers 2012-2014, www.rjustice.eu), to de- 
velop a service which enabled victim self-referral to $\mathrm{RJ}$ and encouraged agencies working with victims (including Victim Support and the Probation Victim Liaison Unit) to make referrals of cases who had indicated interest in meeting 'their' offender.

The funding we applied for has enabled us to appoint three part-time facilitators, a part-time manager, a research interviewer and to cover the costs of RJ conferences. This funding has enabled the staff to participate in international conferences (Barcelona June 2013, Oxford November 2013, Kiel August 2014) to share their experiences of developing and delivering the project. We named our pilot project 'Restoring the Balance', to not only reflect the purposes of RJ to enable victims and offenders to restore the balance in their lives and relationships, but also to restore the balance of access to $\mathrm{RJ}$ as a service for victims of crime.

This article seeks to tell the story of the project so far by describing the work with our early cases and the lessons we have learned from engaging with them. Our practice has taken place while we have developed systems and methods of working to form the foundations of a permanent open access RJ service for victims in the Thames Valley. By telling the story, whilst the pilot project is ongoing, we believe we can give an insight into the process of learning from mistakes as well as from those things we have got right. Ours is not a rigorously scientific approach based on statistical analysis, but one of learning through reflective case supervision and open team discussion which have taken place on a frequent and regular basis.

\section{The legal context}

Where RJ is delivered within a formal part of the criminal justice framework within the UK, it is likely to be initiated through a contact with an offender in relation to pre-sentence RJ (Crime and Courts Act 2013), as mentioned above, or as part of a requirement of a community sentence (Criminal Justice Act 2003). Victims have only been offered the opportunity to take part in RJ following the agreement of the offender in such legal processes.

Victim requested RJ now has the backing of the Victims Code of Practice, which itself has the backing of legislation (Domestic Violence, Crime and Victims Act 2014). It needs to be made clear that the revisions to the Victims Code of Practice (Ministry of Justice, 2013) that enable victims to have access to RJ, and which will help to increase victim awareness of their right to RJ are still to be given substance by key agencies (Police, Victim Support and the Crown Prosecution Service). Much work needs to be undertaken in the UK to inform criminal justice professionals and the public about RJ, so that victims are given the information they need to access RJ, should they wish to.

\section{4 experiences}


The legal context indirectly affects the delivery of $\mathrm{RJ}$ in a number of important ways. The Data Protection Act 1998 has clear implications for the ways in which relevant information is gathered and stored, to enable victim requested RJ cases to proceed. For reasons of space it is not possible to go into these issues in detail, but gaining access to victim and offender information can be a complex and frustrating process for those seeking to facilitate an RJ process. Efforts are taking place both locally and nationally to establish comprehensive information sharing protocols between relevant agencies to facilitate the delivery of $\mathrm{RJ}$, but many difficulties remain which can inhibit, delay, or prevent the process.

Restraining Orders are court orders which have specific terms that may prohibit the offender from making contact with the victim. These orders can prevent the progress of RJ where victims seek to maintain a family relationship, for example. The Restraining Order, originally imposed to protect the victim, then acts as a barrier to communication from victim to offender when the victim may wish to take part in a restorative process. This is an area in which we have had experience during the pilot project. Three out of the fourteen cases have included restraining orders and the issue is dealt with in the learning points covered in this article. Similarly, ongoing criminal appeals against conviction can have a significant bearing on whether victim requested cases can progress until the appeal has been heard.

We would not expect to proceed with RJ where there is an ongoing criminal court case, particularly where there is a 'not guilty' plea. Similarly, where civil proceedings, related to a criminal act, are ongoing this is likely to prevent RJ taking place unless the victim is willing to halt such proceedings and pursue an alternative course of action. All victims and offenders are also advised that if they divulge any information which reveals risk of harm to a child or adult then safeguarding requirements would lead to this information being shared with the appropriate authorities.

\section{Purpose, model used and process}

The purpose of our pilot project has been to develop systems and processes to offer an 'open-access' RJ service to victims in accordance with the provisions of the EU Directive (European Commission, 2012) and to share that learning with European partners, whilst also learning from their experience in implementing similar services.

Our experience has been developed using a scripted conferencing model described fully by John McDonald (McDonald, 2012). This method involves preparing suitable victims and offenders, their families, friends and supporters, to attend a meeting known as an RJ conference. At this meeting the facilitator takes the par- 
ticipants through a scripted process of talking about what happened in an incident of harm; who was affected by what happened; and exploring what can be done to repair the harm. The meeting leads to the preparation of an outcome agreement which describes how harm will be repaired and the outcomes achieved. We have sought to work towards face to face meetings in those cases where this is possible, and explore other options such as indirect communication and letters of apology, where this has not been possible.

The intended process of a typical case (after referral) is to:

- Approach the victim and explain RJ to them, whilst identifying their needs and what they may want from an RJ process.

- Where the victim wants communication with the offender, we will meet the offender and seek their participation in a process of communication, whilst liaising with any professional responsible for offender management.

- A process of preparation is undertaken to establish the wishes and needs of both parties and involve their families and supporters. During this process other professionals working with the parties (offender managers, victim support workers) will also be involved.

- After appropriate preparation with those attending, a scripted conference will be facilitated by a staff member.

- The outcome agreement will be followed up by the facilitator.

- Where the victim decides that they do not wish to have communication the case will not be pursued.

- Where the offender does not agree to take part in any form of communication an alternative process will be discussed. At the outset we had the intention to establish 'healing circles' for victims in these circumstances. We are still working to establish a range of options for victims whose offenders refuse to take part.

\section{The project staff}

Manager: Former Senior Probation Officer with social work and management qualifications. Trained RJ facilitator and ten years of experience managing RJ Projects.

Facilitator 1: Experience of work in legal settings. A trained and experienced family mediator with experience of the use of $R J$ in education settings and recent training in the RJ Conference model for this project. 
Facilitator 2: Career in the management of refugee projects and work with victims of conflict. Trained and experienced in community mediation and conflict resolution. Recent training in the $\mathrm{RJ}$ conference model.

Facilitator 3: Former Police Inspector. Trained and experienced in the delivery of RJ Conferences and experienced RJ trainer (resigned July 2013).

\section{The lessons learned so far}

As already explained the process of learning has taken place through the frequent and regular monitoring of cases in individual supervision between the facilitators and the manager, and in team meetings involving the facilitators and the manager in discussions about how to progress with cases in accordance with best practice (Restorative Justice Council, 2011 and 2014). At each stage we have reflected upon the lessons learned arising from issues presented by the case being discussed.

The issues and learning points which are set out in the following paragraphs are followed by a table which outlines the essential characteristics of each case very briefly. Some of these issues could have arisen whether the case was victim initiated, or offender initiated. Some could have arisen at any stage in the criminal justice process, whilst others specifically relate to RJ work undertaken post-sentence. In some cases we have found answers and learned clear lessons, whilst in other cases the issue remains a matter of ongoing discussion, continuous learning and process development. We acknowledge that many other practitioners, researchers and academics will have worked over this ground before and that many of the practise points are covered in the academic literature. Nevertheless, we believe that the presentation in the form of current learning offers a unique insight into the process of setting up a project and dealing with specific cases. We hope that our experience may assist others, as we have ourselves been helped by learning in collaboration with our European partners, who are grappling with similar issues and dilemmas with their own pilot projects.

\section{Making the service visible and accessible (cases 1 and 14)}

The problem of making a new service visible and accessible to victims is a key issue because one of our aims has been to encourage and facilitate self-referral. Two cases illustrate the nature of this problem. In Case 1, a woman's mentally handicapped adult daughter had been sexually assaulted by her partner. He had been sent to prison for the offence. She wanted advice about how to approach him. Her manager at work (in the care sector) was aware of our RJ project via a colleague. The manager approached us and we wrote to the woman offering 
access to our service. By the time she received our offer she had already visited her partner through the normal family prison visiting process and our offer was not taken up. Had the service been better publicised and more easily accessible, it is likely that we would have been able to offer a facilitated process in a private space.

The second case (Case 14) was a case of household burglary in which the householder wished to meet his offender. The householder had made efforts to seek RJ through the prison chaplaincy without success and was eventually given the Thames Valley Probation RJ phone number and reached us in that way. We rapidly returned his call and he recounted how difficult it had been for him to locate our service and the frustrations of not knowing how to find someone who would facilitate a meeting with the offender. The learning points are clear:

- Provide information to victims about RJ at key points during the criminal justice process.

- Develop a high profile using a range of media, including social media, to bring RJ to the public's attention.

- Have a clear, simple message that makes RJ seem normal, helpful and part of the everyday landscape of criminal justice rather than exotic, heroic and exceptional.

- Make self-referral to the RJ service easy through email, phone and text messaging.

- Provide a swift, open and helpful response to enquiries.

The solution will be for RJ to be offered at all points of the criminal justice system by the provision of information to victims by the professionals involved (Police, Crown Prosecution Service and Victim Support) in a range of helpful formats.

\section{Start with the victim's needs (All cases, best exemplified by case 3 )}

Whilst RJ should be available to all victims who wish to take part and where it would be safe to do so, it is not a universal panacea and should be offered in the context of an appreciation of the victim's wider needs. Offers of RJ made in a crude and insensitive manner, at the wrong time and in the wrong context are counterproductive. This makes take-up of a restorative process less likely and introduces the possibility of re-victimisation. All of our cases exemplify this lesson to a greater or lesser degree. All cases, except Case 6, illustrate a request from the victim to explore what RJ has to offer. The victim in Case 3 was quite specific in his desire to understand whether his attackers maintained a desire to exact revenge. When he received quite specific messages that they did not, he was satisfied and did not wish to pursue a face to face meeting.

Case 6 was referred to see if mediation could provide a resolution to a very long running neighbour/family dispute in which a family had been subject to se-

\section{8 experiences}


vere harassment. In this case the victim was wrongly told that the Police backed the mediation process. This lack of recognition of their status as victims led to a complaint and understandable dissatisfaction on the part of the victims, who felt that their needs had not been recognised.

Learning points:

- Start with an open, listening conversation which seeks to provide information about the service on offer, establish the victim's needs and then, if appropriate, explore the potential for a restorative process.

- Ensure that, throughout the process, the victim's status as the person who has suffered harm is acknowledged and respected.

- Cases where there remains a high level of disputed harm, or an irresolvable dispute about the facts of the case are likely to be unsuitable for an RJ Conference approach, although they may be suitable for community mediation.

\section{When to make an offer of RJ and how to keep the offer open from post incident to, potentially, many years later in such cases as historic abuse (case 5)}

In the future (in accordance with the European Directive, the UK Victim Code of Practice (Ministry of Justice, 2013) and the UK Government's Action Plan (Ministry of Justice, 2012)) victims will be generally made aware of the availability of RJ throughout the progress of their case within the criminal justice system. They will then be able to choose if they want to communicate with, or meet, the offender and at what point it could be helpful to do so. This is described by Wemmers and Van Camp as a 'proactive approach' (Wemmers and Van Camp, 2011). In the meantime we have to make individual selective offers to victims referred to us at key points in the process. This is described by Wemmers and Van Camp as a 'protective approach'. Tinneke Van Camp explored the question of how victims prefer to be approached in relation to the offer of RJ in a workshop at the Oxford conference which formed part of our collaboration (Van Camp, 2013). This presentation which demonstrated victims' preference for a 'proactive approach' has influenced our thinking in relation to how to make our offer of RJ to victims. It will, nevertheless, require a multi-agency approach developed over a period of time to deliver a 'proactive' approach across the span of the criminal justice process. As agencies we (Thames Valley Partnership and Victim Support) are working with the Thames Valley Criminal Justice Board to achieve this, but it will take time.

In our pilot project most of our cases have arisen from agency referrals where a 'protective' approach has been taken. Only two of the fourteen cases have been self-referrals arising from the victim's existing knowledge, or wish for RJ, although 
some of the agency referrals are known to have arisen from requests to meet the offender.

We have to address the fact that not only potential RJ participants, but also the representatives of criminal justice agencies working with them, including police officers, may have limited knowledge of RJ and its potential to repair harm. This presents difficulties in introducing RJ to potential participants and in ensuring that accurate information about $\mathrm{RJ}$ is presented at the right time, in an open and sympathetic manner, without pressure and leaving the door open for involvement at a later stage.

Our cases all illustrate this issue to a greater or lesser degree. Case 5 relates to a failed prosecution of a case of causing death by careless driving in which two people faced allegations after a young man was run over at night by two vehicles. The deceased and both drivers lived in the same area. One driver was deemed too frail to prosecute, whilst the prosecution of the other driver failed for technical and other reasons. The Police referred the case to the project on the basis of the unsatisfactory outcome of the Court process and the unmet needs of the victim's family. The Police Family Liaison Officer (FLO), who had limited knowledge of RJ, discussed the referral with the victim's family and they agreed to consider $\mathrm{RJ}$ as an option. We wrote to them offering our service. Our approach had to wait until there had been a meeting between the family and the Crown Prosecution Service and an inquest had taken place. These factors caused considerable delay in enabling us to make the approach. Following our letter, no response has been received from the victim's family. We have sent a further letter. How far should we go in following up our approach? How do we best convey that the offer remains open? A joint visit by the Family Liaison Officer and an RJ Facilitator would have been the best approach.

Lessons learned:

- Clear and open communication about the availability of RJ and what it can offer provided in leaflets, letters and face to face meetings.

- Separate leaflets for victims and offenders, as well as a general public leaflet and a leaflet for those making referrals.

- Joint introductory meetings to victims with those who make referrals can be helpful. These meetings should focus on giving information to enable a choice, rather than persuasion to take part.

- A proactive approach in which the parties are automatically informed about the availability of $\mathrm{RJ}$ will solve the problem. This will require action at senior manager level in relevant agencies to implement the Victims Code of Practice and the provision of high quality public information.

\section{0 experiences}




\section{Working with victims' relatives affected by crimes (cases $4 \& \mathbf{1 0}$ )}

Close relatives of the victims of crime can be equally, and in some cases more, affected by a crime than the victim themselves. This is well illustrated by Case 10 in which the mother of a young female victim of robbery has been determined to meet her daughter's attackers. Whilst the daughter had been seriously affected by the crime her mother felt more strongly that the offenders should be made aware of the consequences of their actions. The mother's direct experience of the impact of the crime upon her daughter, combined with her own sense of pain and anger about what had occurred, led to an approach being made to the offenders in order to facilitate a process which could lead to a face to face meeting.

Case 4 involves the brother of a murder victim wishing to meet his sister's killer. The murder occurred within the context of domestic abuse. $\mathrm{RJ}$ is advised against in such cases because it is suggested that, in cases with a long history of abuse, it will be impossible to have a dialogue between partners, or ex-partners, on a fair and 'equal' basis, potentially giving the offender an opportunity to use the RJ process to further dominate and manipulate the victim. We had to ask ourselves whether this would be likely in a meeting between the victim's brother and his sister's killer. It seemed to us, both in principle and in the circumstances of this particular case, that the dynamics would be different and not subject to the structural imbalance likely to occur between partners, or ex-partners, in abusive relationships. We have proceeded with the case and a successful conference has now taken place.

Lessons learned:

- Close relatives of those who are the victims of crime can be involved in RJ processes, including face to face conferences, on a similar basis to direct victims. The measure by which suitability can be assessed, in such cases, is the extent to which the impact is felt (and expressed) directly by the victim, or in homicide cases, the victim's family member.

- Family members of victims in fatal domestic abuse cases should not be excluded from RJ processes simply because the victim was subject to a fatal form of domestic abuse. The potential dynamics of the conference should be assessed on a case by case basis in terms of the risks and needs related to the parties involved.

\section{Carefully manage victims' expectations (All cases, exemplified by cas-}

\section{es 4 \& 8)}

Our experience has been that managing the expectations of victims is significantly different from managing the expectations of offenders embarking on RJ. This difference has implications for the facilitator and how they manage their own 
reactions as well as for the participants themselves. This issue needs to be explored in order to understand why and to seek to identify the lessons to be learned.

$\mathrm{RJ}$ requires the offender to take some responsibility for the harm they have caused and to face up to the consequences of their actions. If those consequences include a victim, who has no wish to meet them, then this would appear to be a consequence they have to face up to, without pressure being put on the victim to take part.

Victims however, do not have responsibility for the harm they have suffered and may have some right to expect that their harmer has an obligation to meet them, should they wish to do so. The 'Wait 'til Eight' document (NOMS, 2013), previously referred to, goes so far as to suggest that RJ schemes should operate a'presumption in favour' of RJ. There is an expectation that the offender will take part in RJ unless there are good reasons not to. The offender has to give their consent in the knowledge that meeting the victim may be part of facing up to the consequences of the harm they have caused. This approach is taken on the basis that $\mathrm{RJ}$ is an impartial and fair process in its treatment of both parties, but not a neutral one.

Managing the expectations of offenders, who ask to meet the victim of their crime, is about not raising unrealistic expectations; explaining the kinds of reactions victims may have; indicating that the victim is under no obligation to engage; and avoiding setting up a dynamic whereby the offender blames the victim for letting them down in some way by not agreeing to take part in RJ. Offenders who believe that taking part in RJ post-sentence may give them a reduced penalty or early release, may need to be advised that this is not the case.

Managing the expectations of victims is more complex. Whilst the first part of an approach to victims is to listen to their needs and understand their wishes from a restorative process, this open offer carries a risk. An RJ facilitator can only offer to facilitate communication between two parties who both agree to take part in such a process. Promises cannot be made about whether offenders can be identified, approached, engaged, found suitable, or will agree to take part in an RJ process.

Case 8, an adult woman who was the victim of abuse as a child, perpetrated by an offender who was trusted by her family, is a person who illustrates how carefully expectations must be handled. She has very serious health problems. These problems, when combined with her experience of abuse as a child, make her very vulnerable. She invested a lot in coming forward and giving evidence at a trial some years ago and now believes that her perpetrator should be confronted with the harm he has caused. She believes that this will be both a cathartic process for her and an educative one for her perpetrator which may reduce his likelihood of reoffending. She has been keen to give media interviews explaining her reasons

\section{2 experiences}


for taking part in RJ, believing this may give courage to other victims of abuse. Expectations of this power and intensity need to be handled with care and caution. The practical hurdles are:

- identifying the offender;

- approaching the offender manager and the prison;

- approaching and engaging the offender;

- gaining the offender's trust and consent to an RJ process;

- preparing both parties for a process of communication; and

- achieving a satisfactory outcome for both parties.

At any one of these points the process can break down because one of the parties exercises their right not to engage, or to withdraw. Managing expectations is about making that risk clear throughout the process and avoiding doing harm to either party by setting unrealistic expectations, or making promises. The key to this is a relationship of openness and trust based on understanding needs, exploring options and developing realistic expectations. In Case 8 our victim has received feedback from the RJ Facilitator's first meeting with the offender, who is giving consideration to taking part.

In Case 4 the offender has agreed to meet the brother of his murdered expartner, but the planned face to face meeting was postponed in order to give the offender more time for preparation. This proved difficult for the victim's brother, who had prepared himself for the meeting, but has to manage the uncertainty created by the postponement. Why should he have to work at the pace of the offender? How do we manage the justified irritation and anxiety of the victim's brother following this set back during the process? The victim's brother was told of the offender's need for further preparation, which indicated the importance that the offender attached to the meeting. A date, several months ahead was fixed and preparation processes agreed upon for both parties. The conference has now taken place to the surprise and satisfaction of the victim's brother, who met a man prepared to take responsibility for the harm he had caused.

Learning points:

- Managing the expectations of victims and offenders is different.

- Make an offer of RJ based on an assessment of the victim's needs and wishes, but don't imply that RJ can address all needs. Be prepared to refer and signpost to other agencies for non-RJ related needs.

- The process of working toward communication between victim and offender is long and complex with many hurdles. Victims must be made aware of this as part of the process of preparation and managing expectations. The preparation process itself can be helpful if handled sensitively, but inordinate delay without any apparent reason can be re-victimising. 
- Don't make promises - do build trust. Be open about the causes of delay.

- Respond to disappointments with contact and support, not avoidance. Demonstrate a sense of planning, don't allow drift.

\section{Approaching the offender through the agency'managing' the offend- er. Working with risk averse offender managers and prison staff (Cases 2, 3, 4, 7 and 8)}

In the English criminal justice system the offender manager (formerly Probation Officer) is effectively the gatekeeper to making contact with the offender (in more serious cases) who is subject to community supervision, or serving a prison sentence. Those serving prison sentences are the responsibility of an offender supervisor (prison officer) who seeks to ensure that the sentence plan, prepared by the offender manager, is delivered during the custodial part of the sentence.

Our experience of working with offender managers has been very mixed. Their responses to enquiries to discuss the possibility of approaching 'their' offenders about taking part in restorative justice have varied from open discussion leading to a joint visit to the offender in Case 4, through scepticism and suspicion of our credentials in Case 8, to a complete failure to communicate in Case 2. In Case 3 the OM described one of the offenders as totally unsuitable for a face to face meeting. Consequently the facilitator approached the offender on the basis that an indirect process may be possible. The offender was co-operative, took the victim's fears into account and gave what appeared to be genuine assurances about his future behaviour. He also agreed to meet the victim to explain that he had nothing to fear, although his verbal assurances communicated indirectly to the victim were sufficient for the victim's needs.

We were surprised by the extent of offender managers' ignorance and fear of RJ. Even more surprising was their reluctance, in some cases, to respond to approaches to discuss the possibility. One approach that has paved the way for helpful discussion has been to indicate that the referral has come from a Probation Victim Liaison Unit. A second strategy has been to send enquiries from Probation email addresses (our Facilitators are employed by Probation), but whilst these strategies have had some success they have not worked in all cases. The risk-averse attitude of some offender managers towards $\mathrm{RJ}$ is not altogether surprising, but their lack of awareness of $\mathrm{RJ}$ and its potential to reduce re-offending and address the needs of victims is disturbing.

Staff in prisons have shown similar levels of variation in receptivity towards RJ. This varies from those cases where it is impossible to make contact with the relevant staff member, to Case 4, in which staff in the prison have worked closely to support the offender in working towards $\mathrm{RJ}$ and assist in facilitating the planned

\section{4 experiences}


conference. This case has revealed how important it is to delineate clear roles for the different parties involved in working with the offender. Staff in prison have supported the offender in delaying the planned conference because of a lack of confidence on the part of the offender. We wonder if they could have done more to support the offender to go ahead. This would avoid putting the victim to considerable inconvenience and upset. Could we have anticipated this problem? The prisoner had a recent history of risk of self-harm, and perhaps a better strategy of support and preparation could have been put in place to avoid postponement.

In Case 7 the prison took a very protective attitude towards the prisoner, who was involved in considering how to respond to an invitation to take part in $\mathrm{RJ}$ and subsequently the preparation of a letter of apology. The lack of consideration of the needs of the victim in this process, and the exclusive focus on the prisoner and his needs at the time, required an approach which shifted the focus of the work of prison staff towards including a more developed victim perspective. Ultimately, a positive outcome was achieved, namely a letter of apology which addressed the questions and concerns of the victim.

Learning points:

- Engaging offender managers is essential in cases where offenders are in prison or under the supervision of the Probation Service.

- Offender managers need to be made more aware of the potential for RJ to bring benefits to both offenders and victims, in general terms and at the level of the individual case.

- Once RJ work is embarked upon the RJ Facilitator, the offender manager and the offender supervisor need to agree upon clear roles and responsibilities in relation to the progress of the case and to update each other regularly.

- Work with prison staff must ensure that the needs of both victim and offender are taken into account and that the interests of both parties are recognised in the preparation and planning process.

\section{Restraining Order issues and cases subject to appeal (Cases 6, 10, 11} and 12)

Restraining orders are orders given by the court at the time of sentence. They have specific terms that prohibit the offender from making contact with the victim. They will have effect during the course of a prison sentence and after release. The aim of the order is to protect the victim and, if breached by the offender, punishments can be imposed for the breach, including imprisonment. Such orders are usually seen as preventing RJ, but they may contain provisos such as 'no contact without the agreement of the supervising probation officer'. 
In two cases ( $11 \& 12)$ mothers who have been gravely attacked or threatened by their sons, have been referred at their own request because they want news of their son's progress and may want direct, or indirect contact. In these cases the Restraining Order is preventing mothers, who have suffered significant harm, from learning about the welfare of their sons and demonstrating that they care for them despite the harm they have suffered. The mothers both want to explore how information can be exchanged and whether contact can be made that could be safe and beneficial to both parties. Both mothers are prepared for the process to take time and do not, at this stage, have specific requests about the nature of the contact.

Case 10 involved an offender who was engaged in an appeal against conviction. This was not clear at the time of referral and, despite many requests for the relevant information, only became clear in a face to face interview with the offender which was not the best point at which to approach him about RJ.

Learning points:

- It is good practice to discuss the case with the authority which requested the injunction, usually the Police or the Crown Prosecution Service, at an early stage and before embarking on a restorative process which could involve direct or indirect contact between the parties.

- We have received advice that for us to explore the possibilities of $\mathrm{RJ}$ is not, in itself, a breach of the injunction (in this case, a restraining order). It is best to ask the victim for a copy of the order before proceeding.

- If contact is then planned which is outside the terms of the order, then application should be made to the court (by the victim) to have the order amended to allow contact to take place within the context of a restorative process.

- Cases involving appeals against conviction are usually unsuitable and this should be checked at the point of referral. Cases involving appeals against sentence have not been encountered by our project, but are likely to raise complex issues which would usually mean that RJ should not be commenced until the appeal has been dealt with.

\section{How to manage confidential information about offender and the question of sharing information to aid the process or provide reassurance (Cases 2 and 8)}

In Cases 2 and 8 information about the offender's current circumstances have become apparent during the course of preparation which would be of interest and assistance to the victim in Case 2 and of concern to the victim in Case 8. In both cases the offender is in prison. In both cases there are issues of confidentiality

\section{6 experiences}


which are not clear cut. In Case 2 the issue relates to the offender's frailty and attitude to meeting the victim. In Case 8 the issue relates to the offender's ambivalent attitude towards meeting the victim. The dilemma is about whether to: provide this information to the victims as part of preparation and feedback in the course of preparation towards a restorative process, thereby providing reassurance in Case 2 and explanation for delay in Case 8. Or, to treat the information as confidential to the offender and having a potential to weaken the power of the face to face conference, if one should take place.

For us this issue has been greatly assisted by the presentation made by Kristel Buntinx at the Kiel Conference (Buntinx, 2014) which has validated our approach of sharing information about the other party's attitude towards meeting and taking part in a restorative process. Sharing this kind of information is part of the process of preparation and not strictly information that is confidential. This tends toward blurring the distinction between the RJ conference model and victim-offender mediation, which is referred to by Shapland (Shapland, 2013). Nevertheless, by sharing such information in very serious cases, the parties can make an informed choice based on information that is necessary, reliable and helpful to enable them to go forward. If both parties are aware that such information is being shared the process is fair and not in breach of the principles of confidentiality.

Learning point:

- Share information between the parties where the parties have given their permission and this will reduce fear and provide steps towards potentially constructive communication. 
Table 1. Table of Cases and Learning Points Identified (Referrals April 2013 to March 2014)

\begin{tabular}{|c|c|c|c|c|c|c|}
\hline $\begin{array}{l}\text { Case } \\
\text { Ref }\end{array}$ & $\begin{array}{l}\text { Ref } \\
\text { By }\end{array}$ & $\begin{array}{l}\text { Brief descrip- } \\
\text { tion }\end{array}$ & Offence & $\begin{array}{c}\text { Stage } \\
\text { in Criminal } \\
\text { Justice } \\
\text { Process } \\
\end{array}$ & Key Lessons & $\begin{array}{c}\text { Outcome or } \\
\text { stage } \\
\text { reached } \\
\text { in RJ Process }\end{array}$ \\
\hline 1 & Friend & $\begin{array}{l}\text { Mother of victim } \\
\text { whose adult } \\
\text { daughter with } \\
\text { severe learning } \\
\text { difficulties had } \\
\text { been abused by } \\
\text { mother's partner, } \\
\text { who is now in } \\
\text { prison. }\end{array}$ & $\begin{array}{l}\text { Sexual } \\
\text { offence } \\
\text { against a } \\
\text { person with } \\
\text { a mental } \\
\text { handicap }\end{array}$ & $\begin{array}{l}\text { Post- } \\
\text { sentence } \\
\text { (prison) }\end{array}$ & $\begin{array}{l}\text { Improve } \\
\text { accessibility, } \\
\text { speed and } \\
\text { profile of service } \\
\text { available to } \\
\text { victims and their } \\
\text { families. }\end{array}$ & $\begin{array}{l}\text { Mother of } \\
\text { victim made } \\
\text { visit to } \\
\text { offender in } \\
\text { prison without } \\
\text { seeking the } \\
\text { assistance of } \\
\text { our service. } \\
\text { Case not } \\
\text { proceeded } \\
\text { with. }\end{array}$ \\
\hline 2 & VLU & $\begin{array}{l}\text { Victim of historic } \\
\text { child abuse } \\
\text { who now wants } \\
\text { to meet her } \\
\text { perpetrator } \\
\text { (father) in } \\
\text { adulthood. }\end{array}$ & $\begin{array}{l}\text { Child sex } \\
\text { offences }\end{array}$ & $\begin{array}{l}\text { Post- } \\
\text { sentence } \\
\text { (prison) }\end{array}$ & $\begin{array}{l}\text { - How to approach } \\
\text { OM of offender. } \\
\text { The OM will not } \\
\text { communicate } \\
\text { and seems } \\
\text { fearful/ ignorant } \\
\text { of RJ. } \\
\text { - How to manage } \\
\text { confidential } \\
\text { information } \\
\text { about the } \\
\text { offender which, } \\
\text { if revealed to the } \\
\text { victim, would } \\
\text { reduce her fear. }\end{array}$ & $\begin{array}{l}\text { Victim fearful } \\
\text { and wants } \\
\text { to pursue } \\
\text { meeting. } \\
\text { Difficulties in } \\
\text { approaching } \\
\text { offender in } \\
\text { prison. }\end{array}$ \\
\hline 3 & VLU & $\begin{array}{l}\text { Victim fearful } \\
\text { of group of } \\
\text { offenders who } \\
\text { attacked him. } \\
\text { Victim fears } \\
\text { violence } \\
\text { after they are } \\
\text { released from } \\
\text { prison. }\end{array}$ & $\begin{array}{l}\text { Wounding, } \\
\text { theft and } \\
\text { common } \\
\text { assault }\end{array}$ & $\begin{array}{l}\text { Post- } \\
\text { sentence } \\
\text { (prison) }\end{array}$ & $\begin{array}{l}\text { - Be clear about } \\
\text { what victim } \\
\text { wants/needs } \\
\text { - How to deal } \\
\text { with risk averse } \\
\text { offender } \\
\text { managers. } \\
\text { - Deal with } \\
\text { offenders one } \\
\text { at a time. } \\
\text { - Keep feeding } \\
\text { back to victim. } \\
\text { - Exchanging too } \\
\text { much information } \\
\text { between parties } \\
\text { can preclude face } \\
\text { to face RJ. }\end{array}$ & $\begin{array}{l}\text { Offenders } \\
\text { seen in prison, } \\
\text { by facilitator, } \\
\text { and offered } \\
\text { re-assurance. } \\
\text { Victim } \\
\text { reassured and } \\
\text { does not need } \\
\text { to meet. }\end{array}$ \\
\hline
\end{tabular}

\section{8 experiences}




\begin{tabular}{|c|c|c|c|c|c|c|c|}
\hline 4 & VLU & $\begin{array}{l}\text { Murder victim's } \\
\text { brother wants to } \\
\text { meet murderer } \\
\text { of his sister in } \\
\text { prison. }\end{array}$ & Murder & $\begin{array}{l}\text { Post-sentence } \\
\text { (prison) }\end{array}$ & & $\begin{array}{l}\text { Carefully } \\
\text { manage victim's } \\
\text { expectations. } \\
\text { Work } \\
\text { collaboratively } \\
\text { with OM and } \\
\text { prison staff - needs } \\
\text { careful delineation } \\
\text { of roles. } \\
\text { Introduce RJ to } \\
\text { prisoner carefully, } \\
\text { allow him to } \\
\text { request a meeting. }\end{array}$ & $\begin{array}{l}\text { Conference } \\
\text { taken place, } \\
\text { offender } \\
\text { acknowledged } \\
\text { responsibility. } \\
\text { Victim gained } \\
\text { answers to key } \\
\text { questions. }\end{array}$ \\
\hline 5 & Police & $\begin{array}{l}\text { Collapsed trial of } \\
\text { causing death by } \\
\text { careless driving } \\
\text { where all parties } \\
\text { (victim's family } \\
\text { and two alleged } \\
\text { perpetrators) live } \\
\text { in same village. }\end{array}$ & $\begin{array}{l}\text { Alleged } \\
\text { case of } \\
\text { causing } \\
\text { death by } \\
\text { careless } \\
\text { driving }\end{array}$ & $\begin{array}{l}\text { After failed } \\
\text { prosecution. } \\
\text { (Due to } \\
\text { errors in } \\
\text { investigation) }\end{array}$ & & $\begin{array}{l}\text { When is the right } \\
\text { time to make offer } \\
\text { of RJ? } \\
\text { How can offer } \\
\text { of RJ be kept } \\
\text { open throughout } \\
\text { CJ process and } \\
\text { beyond? } \\
\text { What could we } \\
\text { offer in a case } \\
\text { where complex } \\
\text { civil litigation is } \\
\text { possible? }\end{array}$ & $\begin{array}{l}\text { Offer of RJ } \\
\text { made to } \\
\text { victim's family. } \\
\text { No response. }\end{array}$ \\
\hline 6 & VSS & $\begin{array}{l}\text { Family feud in } \\
\text { small village has } \\
\text { led to previous } \\
\text { threats and } \\
\text { violence. Long- } \\
\text { term intractable } \\
\text { problem. }\end{array}$ & $\begin{array}{l}\text { Violence } \\
\text { and } \\
\text { breach of } \\
\text { restraining } \\
\text { orders }\end{array}$ & $\begin{array}{l}\text { Post breach } \\
\text { of restraining } \\
\text { order in } \\
\text { criminal } \\
\text { proceedings }\end{array}$ & & $\begin{array}{l}\text { How to work in } \\
\text { a case where a } \\
\text { Restraining Order } \\
\text { is in place between } \\
\text { the parties. } \\
\text { How to deal with } \\
\text { resistance of other } \\
\text { agencies to RJ. }\end{array}$ & $\begin{array}{l}\text { Withdrawn } \\
\text { due to further } \\
\text { incidents under } \\
\text { investigation } \\
\text { by Police. }\end{array}$ \\
\hline 7 & VLU & $\begin{array}{l}\text { Young victim } \\
\text { of rape (now } \\
\text { adult) in fear of } \\
\text { offender's release } \\
\text { from prison. }\end{array}$ & Rape & $\begin{array}{l}\text { Post-sentence } \\
\text { (prison) }\end{array}$ & & $\begin{array}{l}\text { Dealing with } \\
\text { protectiveness of } \\
\text { prison staff. } \\
\text { Use of indirect } \\
\text { process. } \\
\text { Need for } \\
\text { continuous up- } \\
\text { dating of 'referrer'. }\end{array}$ & $\begin{array}{l}\text { Offender } \\
\text { wrote letter to } \\
\text { victim which } \\
\text { addressed her } \\
\text { concerns. }\end{array}$ \\
\hline 8 & VLU & $\begin{array}{l}\text { Victim of historic } \\
\text { child abuse now } \\
\text { wants to meet } \\
\text { her perpetrator in } \\
\text { adulthood. }\end{array}$ & $\begin{array}{l}\text { Child sex } \\
\text { offences }\end{array}$ & $\begin{array}{l}\text { Post-sentence } \\
\text { (prison) }\end{array}$ & & $\begin{array}{l}\text { Managing victim's } \\
\text { expectations. } \\
\text { Use of media when } \\
\text { victim wants her } \\
\text { story told. }\end{array}$ & $\begin{array}{l}\text { Offender } \\
\text { considering } \\
\text { whether to } \\
\text { meet face to } \\
\text { face. }\end{array}$ \\
\hline
\end{tabular}


Ljetopis socijalnog rada 2015., 22 (1), 81-104 str.

\begin{tabular}{|c|c|c|c|c|c|c|}
\hline 9 & Self & $\begin{array}{l}\text { Offender } \\
\text { sentenced to RJ } \\
\text { for robbery, but } \\
\text { failed to attend } \\
\text { during order. } \\
\text { Victim still wants } \\
\text { to meet. }\end{array}$ & Robbery & $\begin{array}{l}\text { Post-sentence } \\
\text { (prison) }\end{array}$ & $\begin{array}{l}\text { - Change in } \\
\text { circumstance may } \\
\text { reduce need for } \\
\text { RJ. }\end{array}$ & $\begin{array}{l}\text { Victim } \\
\text { requested } \\
R J \text { and then } \\
\text { withdrew after } \\
\text { going away to } \\
\text { university. }\end{array}$ \\
\hline 10 & YOT & $\begin{array}{l}\text { Mother of young } \\
\text { female victim } \\
\text { of robbery } \\
\text { wants to meet } \\
\text { her daughter's } \\
\text { attackers. }\end{array}$ & Robbery & $\begin{array}{l}\text { Post-sentence } \\
\text { (prison) }\end{array}$ & $\begin{array}{l}\text { Working with } \\
\text { victim's relative } \\
\text { affected by crime. } \\
\text { Appeal cases likely } \\
\text { to be unsuitable. }\end{array}$ & $\begin{array}{l}\text { Offender } \\
\text { refusal, } \\
\text { appealing } \\
\text { against } \\
\text { conviction, to } \\
\text { be approached } \\
\text { again after } \\
\text { appeal. }\end{array}$ \\
\hline 11 & VLU & $\begin{array}{l}\text { Mother who } \\
\text { is victim of } \\
\text { violence from } \\
\text { son. }\end{array}$ & IPP & $\begin{array}{l}\text { Post-sentence } \\
\text { (prison) }\end{array}$ & $\begin{array}{l}\text { - Restraining order } \\
\text { issues. } \\
\text { Managing } \\
\text { meeting between } \\
\text { close relatives } \\
\text { who have not } \\
\text { seen each other } \\
\text { for years. } \\
\text { - Geographical } \\
\text { distance between } \\
\text { victim and } \\
\text { offender who is in } \\
\text { distant prison. }\end{array}$ & $\begin{array}{l}\text { Victim } \\
\text { considering } \\
\text { options. }\end{array}$ \\
\hline 12 & VLU & $\begin{array}{l}\text { Mother who } \\
\text { is victim of } \\
\text { violence from } \\
\text { son. }\end{array}$ & IPP & $\begin{array}{l}\text { Post-sentence } \\
\text { (prison) }\end{array}$ & $\begin{array}{l}\text { Restraining order } \\
\text { issues. } \\
\text { Managing } \\
\text { meeting between } \\
\text { close relatives } \\
\text { who have not } \\
\text { seen each other } \\
\text { for years. } \\
\end{array}$ & $\begin{array}{l}\text { Victim } \\
\text { considering } \\
\text { her options, } \\
\text { wishes to } \\
\text { proceed } \\
\text { slowly. }\end{array}$ \\
\hline 13 & YOT & $\begin{array}{l}\text { Female victim, } \\
\text { age } 17, \text { of } \\
\text { robbery who } \\
\text { had expressed } \\
\text { interest in } \\
\text { meeting } \\
\text { offender at } \\
\text { presentence } \\
\text { stage. }\end{array}$ & Robbery & $\begin{array}{l}\text { Post-sentence } \\
\text { (community) }\end{array}$ & $\begin{array}{l}\text { Offender attitude } \\
\text { and motivation } \\
\text { can only be } \\
\text { assessed by } \\
\text { interview. } \\
\text { - Consistency of } \\
\text { support to enable } \\
\text { conference to be } \\
\text { undertaken by } \\
\text { young victim. }\end{array}$ & $\begin{array}{l}\text { Conference } \\
\text { blocked by } \\
\text { victim's father } \\
\text { due to his } \\
\text { mistrust of } \\
\text { offender's } \\
\text { motives. }\end{array}$ \\
\hline 14 & Self & $\begin{array}{l}\text { Burglary victim } \\
\text { who wants to } \\
\text { meet the burglar } \\
\text { in prison. }\end{array}$ & Burglary & $\begin{array}{l}\text { Post-sentence } \\
\text { (prison) }\end{array}$ & $\begin{array}{l}\text { Victim had } \\
\text { great difficulty } \\
\text { in locating our } \\
\text { service. }\end{array}$ & $\begin{array}{l}\text { Victim } \\
\text { withdrew due } \\
\text { to delay. }\end{array}$ \\
\hline
\end{tabular}

\section{0 experiences}




\section{Glossary and notes:}

VLU = Probation Victim Liaison Unit: whose role is to contact victims of sexual and violent offences, where the sentence is one of 12 months' imprisonment or more. The service provides victims with information about how the sentence will operate, including the opportunity to make a statement to parole hearings and request postrelease licence conditions, including non-contact conditions and exclusion zones e.g. around the victim's home.

YOT = Youth Offending teams deal with young offenders (up to 18) and their victims.

OM = Offender Manager (formerly Probation Officer) - the person responsible for the offender's overall sentence plan whilst in custody and supervision in the community.

OS = Offender Supervisor - the prison based staff member who has responsibility for ensuring that the sentence plan is carried out whilst the offender is in prison.

IPP = Indeterminate sentence for Public Protection. An indeterminate sentence is passed when an offender has committed a grave offence and is deemed to be dangerous (within specific criteria). The sentence has a tariff period, determined by the seriousness of the offence, after which the offender may be released, if no longer considered to be a risk to the public.

Restraining Order $=$ an order, which has specific terms, that prohibit the offender from making contact with the victim.

Note: Not all learning points identified in the table have been covered in the text due to lack of space.

\section{CONCLUSIONS}

Making RJ accessible to victims is more than just passing legislation and changing codes of practice, it requires a process of public information and education, as well as informing relevant professionals of the power of $\mathrm{RJ}$ to meet the needs of a significant proportion of victims, who have been harmed both by crime and in many cases by the criminal justice system itself.

We have learned that there is no such thing as a typical case. What follows from this is that whilst systems and processes are necessary to deliver an effective service, the victims' needs and wishes must not be made to fit the systems and processes, but rather the systems and processes need to be sufficiently flexible to accommodate an almost infinite range of possibilities in terms of victim need and offender response. This is further complicated by the requirement to work with offenders through those who have responsibility for offender management and 
public protection. The criminal justice process is extremely complex for victims to negotiate their way through. RJ must be delivered in a way that does not increase that complexity and confusion, without compromising its independence from the system.

The cases referred to in our pilot project continue to be progressed towards a restorative outcome; new referrals continue to be accepted and worked with; and a permanent service is being developed to continue the work of the EU pilot project. This service will be funded by the Thames Valley Police and Crime Commissioner. Valuable lessons have been learned through our own shared practice, as well as through discussion and participation in the EU collaboration. The EU collaboration has not only provided the opportunity to share the experience of setting up and delivering pilot projects, but also through learning from experts in the RJ field, including both practitioners and academics. We have described how we have applied learning from Tinneke Van Camp, Kristel Buntinx and our European colleagues, in a direct and practical way, to progress our casework with victims. This learning will form a platform of expertise and skill to ensure that our service continues to improve and is accessible, inclusive, and safe, and avoids the possibility of re-victimisation.

\section{REFERENCES}

1. Buntinx, K. (2014). Victim-offender mediation in cases of homicide: Chances and risks. Kiel: Presentation at Kiel University of Applied Sciences. Available at: www.rjustice.eu

2. Emerson G. (2011). The state of restorative justice in England and Wales. In: Lummer, R., Hagemann, O. \& Tein, J. (eds.), Restorative justice - A European and Schleswig-Holsteinian perspective. Kiel: Schleswig-Holstein Association for Social Responsibility in Criminal Justice. Available at www.rjustice.eu.

3. Emerson, G. (2012). What a difference a year makes. In: Lummer, R., Nahrwold, M. \& Suss, B. (eds.), Restorative justice - A victim perspective and issues of co-operation. Kiel: Schleswig-Holstein Association for Social Responsibility in Criminal Justice. Available at www.rjustice.eu.

4. European Commission (2012). Establishing the minimum standards on the rights, support and protection of victims of crime. Directive of the European Parliament of the Council $25^{\text {th }}$ October 2012.

5. Lummer, R., Hagemann, O. \& Tein, J. (eds.) (2011). Restorative Justice - a European and Schleswig-Holsteinian perspective. Kiel: Schleswig-Holstein Association for Social Responsibility in Criminal Justice, Victim and Offender Treatment, Kiel University of Applied Sciences. 
6. Lummer, R. Nahrwold, M. \& Suess, B. (eds.) (2012). Restorative justice - A victim perspective and issues of co-operation. Kiel: Schleswig-Holstein Association for Social Responsibility in Criminal Justice, Victim and Offender Treatment, Kiel University of Applied Sciences.

7. McDonald, J. (2012). Best practice in restorative justice facilitation: Some big ideas in restorative justice, adults and emerging practice. Sydney: Sydney Institute of Criminology.

8. Ministry of Justice (2012). Restorative justice action plan for the criminal justice system. Available at: www.gov.uk/government/.../restorative-justiceaction-plan.pdf

9. Ministry of Justice (2013). Code of practice for victims of crime. London: The Stationery Office. Available at: at:www.cps.gov.uk/publications/docs/victims_code_2013.pdf.

10. National Offender Management Service (NOMS) (2013). Wait 'til eight - An essential start-up guide to NOMS RJ implementation. Chilton: Thames Valley Partnership

11. Restorative Justice Council (2011). Best practice guidance for restorative practice. London: RJC.

12. Restorative Justice Council (2014). How to engage victims in a restorative process. London: RJC

13. Schleswig-Holstein Association for Social Responsibility in Criminal Justice, Victim and Offender Treatment (2013-2014). Restorative justice at the postsentencing level; Supporting and protecting victims. Project proposal and conference papers. Available at: www.rjustice.eu

14. Shapland, J., Atkinson, A., Atkinson, H., Chapman. B., Dignan, J., Howes, M. Johnstone, J., Robinson G. \& Sorsby, A. (2006). Restorative Justice: The views of victims and offenders. The third report from the evaluation of three schemes. Sheffield: Centre for Criminological Research, University of Sheffield

15. Shapland, J., Atkinson, A., Atkinson, H., Dignan, J., Edwards, L., Hibbert, J., Howes, M. Johnstone, J., Robinson G. \& Sorsby, A. (2006). Does restorative justice affect reconviction? The fourth report from the evaluation of three schemes. Sheffield: Centre for Criminological Research, University of Sheffield

16. Shapland, J., Robinson, G. \& Sorsby, A. (2011). Restorative justice in practice: Evaluating what works for victims and offenders. London: Routledge

17. Shapland (2013) Implications of growth: Challenges for restorative justice. International Review of Victimology, 20 (1), 111-127.

18. Thames Valley Police and Crime Commissioner (2014). Victims service commissioning intentions. Available at: www.thamesvalley-pcc.gov.uk 
Ljetopis socijalnog rada 2015., 22 (1), 81-104 str.

19. Van Camp, T. (2013). Do victims of violent crime prefer a proactive or protective approach to the offer of restorative justice? Oxford: Presentation at St Catherine's College. Available at: www.rjustice.eu

20. Wemmers, J. \& Van Camp, T. (2011). The offer of restorative justice to victims of violent crime: Should it be proactive or protective? Final Report. Montreal: CICC Universite de Montreal

\author{
Geoff Emerson \\ Louise Carrington-Dye \\ Graham Dix \\ Diane Grammer
}

Thames Valley Partnership

Chilton

Ujedinjeno Kraljevstvo Velike Britanije i Sjeverne Irske

\title{
POVRAT RAVNOTEŽE: POUKE IZ SLUČAJEVA EU PILOT-PROJEKTA U REGIJI THAMES VALLEY, UK KOJI OMOGUĆUJE RESTORATIVNU PRAVDU NA ZAHTJEV ŽRTVE
}

\section{SAŽETAK}

Članak opisuje pouke iz pilot-projekta koji restorativnu pravdu omogućuje žrtvama zločina na koje upućuju agencije za pomoć žrtvama te žrtvama koje se same prijave za takav program. Projekt uključuje partnerstvo agencija u regiji Thames Valley, koje djeluju u sklopu šire europske suradnje, kako bi se usluge restorativne pravde za žrtve proširile na razini nakon izricanja kazne. Žrtvama omogućujemo pristup restorativnoj pravdi, dok štitimo njihova prava i sprečavamo ponovnu viktimizaciju, u skladu s Direktivom 2012/29/EU (Europska komisija 2012.).

Objašnjeni su kontekst i metodologija pilot-projekta, a potom su kroz timske rasprave o slučajevima i superviziju identificirane i opisane pouke iz prakse. Slučajevi su sažeti u tablici koja navodi njihove ključne značajke kao referentne točke.

U vrijeme pisanja članka, slučajevi su u tijeku. Pouke se ne mogu još uvijek jasno definirati i finalizirati. Vjerujemo da će ovaj pristup pokazati proces učenja iz iskustva i prakse kako se projekt bude razvijao. lako naš pristup nije strogo znanstven, nadamo se da nudi priliku da se razumiju dileme i pitanja predstavljene modelom koji počinje zahtjevom žrtve za restorativnom pravdom. Neovisna procjena, koja uključuje intervjue sa žrtvama, posrednicima i počiniteljima koji su sudjelovali u pilot-projektu, slijedi u kasnijoj fazi.

Ključne riječi: pouke, restorativna pravda, žrtve, pristup 